\title{
OS ASPECTOS FORMATIVOS DA PAIDEIA FILOSÓFICA DE PLATÃO: CONTRIBUI- ÇÕES DO PROJETO DE EMANCIPAÇÃO HELÊNICO PARA UMA EDUCAÇÃO HU- MANÍSTICA CONTEMPORÂNEA
}

\section{Guilherme Prado Roitberg*}

RESUMO: Considerando a longa duração da paideia grega como ideal de formação integral e humanista, bem como a permanência dos elementos paidêuticos no campo da cultura e da educação ocidental, o presente trabalho analisará os aspectos formativos da paideia filosófica de Platão e seu sentido na contemporaneidade, tendo como base as formulações teóricas presentes em suas obras à luz dos debates acerca do tema.

Palavras-chave: Paideia; Platão; Humanismo; Formação; Emancipação.

RESUMEN: Considerando tanto la larga duración de la paideia griega como ideal de formación integral y humanista, así como la permanencia de los elementos paidêuticos en el campo de la cultura y la educación occidental, el presente trabajo analizará los aspectos formativos de la paideia filosófica de Platón y su sentido en la contemporaneidad, teniendo como base las formulaciones teóricas presentes en sus obras a la luz de los debates sobre el tema.

Palabras clave: Paideia; Platón; Humanismo; Formación; Emancipación.

\section{Introdução}

O presente artigo constitui parte de uma dissertação de mestrado em andamento, que tem por objeto as origens históricas da paideia ${ }^{2}$ grega e as contribuições do filósofo Platão (428/427-348/347 a.C.) na consolidação desse ideal formativo. $\mathrm{O}$ estudo de um tema tão amplo e complexo como a paideia, bem como as implicações temporais da investigação do período da Antigui-

\footnotetext{
* Mestrando em Educação pela Universidade Estadual Paulista "Julio de Mesquita Filho", campus de Rio Claro-SP. Contato: guilhermeroitberg@gmail.com

${ }^{2}$ Segundo Jaeger (2013, pp.8-9) a melhor definição para o tema histórico da paideia seria a formação do homem grego. Para o autor, os gregos tiveram um papel de destaque através do seu ideal de formação humana: foi a partir do mundo helênico que a cultura passou a ser concebida enquanto um ideal formativo, onde a paideia não seria algo "exterior à vida", mas elemento constituinte da própria formação humana em sua totalidade.
}

dade clássica, nos trazem algumas questões às quais devemos nos atentar. Diversos autores salientam os cuidados com os procedimentos metodológicos e com a maneira de abordar o tema. Jaeger (2013) é contundente ao destacar a necessidade e o desafio de tentar entender o que a paideia representava para os homens gregos em seu contexto, sem ignorar, contudo, a sua importância e influência sobre educação e a cultura ocidental em um plano mais amplo. Com base nessa perspectiva histórica, nosso artigo trabalhará com uma linha que diferencie a concepção grega de formação, educação e cultura da acepção contemporânea desses conceitos. Em um segundo momento, analisaremos aos elementos formativos da paideia, a permanência dos elementos paidêu-

ROITBERG, Guilherme Prado. Os aspectos formativos da paideia filosófica de Platão: Contribuições do projeto de emancipação helênico para uma educação humanística contemporânea. Revista SulAmericana de Filosofia e Educação. Número 30: nov./2018-abr.2019, p. 91-108. DOI: https://doi.org/10.26512/resafe.vi3o.28245 
ticos ao longo da história e suas contribuições no contexto da contemporaneidade.

\section{As origens históricas da paideia: da tra- dição mitopoética à arete política}

No contexto anterior à criação das primeiras escolas do período clássico, o centro da formação na Grécia arcaica era a educação familiar, o primeiro lugar de socialização, onde o indivíduo reconhecia a si e aos outros, aprendendo noções sobre regras, valores e a própria concepção de mundo. A família não somente possuía um papel na formação ideológica, como instituía uma regulação moral e física sobre as crianças; organizava-se a partir do genos (estirpe, descendência comum) um modelo patriarcal, autoritário, centrado no pai, cuja união (de várias gens) originou a comunidade social que deu vida à pólis (CAMBI, 1999, p.8o). Em contrapartida, o oikos (espaço familiar) era o espaço onde reinava a mulher - esposa, mãe, socialmente subalterna e sem voz - local onde se desenvolvia a vida feminina, organizadora da vida famíliar que, todavia, é reinada pela lei masculina que censura e sanciona (DUBY e PERROT apud CAMBI, 1999, p.81).

Historiadores e filósofos da Educação como Jaeger (2013), Cambi (1999), Marrou (1975) e Manacorda (1992) consideram as obras de Homero como ponto de partida para os estudos sobre a educação grega, dado o papel central de sua epopeia na formação arcaica e clássica. No período arcaico (aproximadamente 800 a.C.-500 a.C.), assim como ocorre com as civilizações "bárbaras" na antiguidade, a educação voltava-se, sobretudo para a formação de uma aristocracia de guerreiros, com base no ensinamento de valores, na constituição do caráter e do vigor físico (MARROU, 1975, p.7). No mundo helênico3 ${ }^{3}$ essa passagem pode ser notada nas epopeias Ilíada e Odisseia. Antes de serem lidas, essas obras já eram recitadas e cantadas, exaltando a atividade física, a honra e a atividade do nobre guerreiro, valores aristocráticos reunidos sob o conceito de arete ${ }^{4}$ : o ideal de educação da época arcaica, constituído como ideal representativo de toda uma cultura aristocrática, cujo testemunho mais remoto localiza-se sobretudo através dos exemplos heroicos como os

\footnotetext{
3 No período da Antiguidade, a hélade correspondia ao mundo grego, ou seja, ao conjunto de todos os povos que consideravam a si mesmos como "helenos" e habitavam as terras entre o Mar Egeu e o Mar Mediterrâneo. Essa civilização - cujas origens mais remotas correspondem aos povos que ocuparam a Ilha de Creta por volta de 6000 a.C. - passou por uma série de transformações e ocupações de povos advindos de diversas regiões, como os aqueus, eólios, dóricos, jônios, e finalmente, com o domínio dos povos micênicos. Sem formar um império unificado, a Grécia era dividida em cidades-estado (pólis) independentes, que possuiam suas próprias leis, mas partilhavam de uma cultura em comum (PEREIRA, 1998, pp.31-36).

${ }_{4}$ As expressões arete e paideia - conceitos inseparáveis no mundo helênico, mas de tradução impossível para a nossa língua - não se reduzem respectivamente às concepções de "virtude"/"excelência" e "formação", por mais que essas palavras sejam as mais próximas utilizadas na língua portuguesa na tradução desses conceitos (ver GROSS, 2005; JAEGER, 2013; MARROU, 1975, CAMBI, 1999; PLATÃO 2010a e 2010b). No decorrer da história da educação ocidental, "ambos os conceitos evoluíram, mas conservando sempre os sentidos de nobreza e de formação, indicando uma educação de espectro integral e tridimensional", um verdadeiro ideal de educação cujos principais objetivos seriam "a formação harmônica mente, corpo e coração", ou seja, "uma formação intelectual, física e virtuosa" (GROSS, 2005, p.22).
} 
nobres guerreiros Ulisses e Aquiles (JAEGER, 2013, p. 25; HOMERO, 2015a e 2015b). A tradição mitopoética permaneceu durante séculos como o eixo norteador da formação aristocrática arcaica e clássica. Segundo Finley (1989, p.6), "o mito era o grande mestre dos gregos em todas as questões do espírito. Com ele, aprendiam a moralidade e a conduta; as virtudes da nobreza", bem como questões sobre "raça, cultura e até mesmo política”. Para Malinowkski, por Burke, "os mitos" seriam "histórias com funções sociais", como um "alvará", uma "história fictícia" que "desempenha a função de justificar alguma instituição no presente e, desse modo, manter sua existência" (MALINOWSKI apud BURKE, 2012, p.171). No caso grego, a permanência do mito pode ser percebida mesmo após o advento da filosofia socrática, como é possivel notar a partir dos textos platônicos A República e As Leis.

Ao investigar os textos da Ilíada e da Odisséia, Mossé (1984, pp.89-91) buscou encontrar nas (entre)linhas da poesia homérica a emergência do "fator político". Para o autor, a passagem de Ulisses por um julgamento realizado na ágora ${ }^{5}$ demonstra o poder dos anciãos como intermediadores de conflitos "em nome de Zeus". Essa cena evocaria "os primórdios da cidade-estado", onde o poder estava "unicamente nas mãos dos basileus", as autoridades reais do período arcaico. Nesse cenário político, o povo já tomava partido nas discussões, apoiando uma ou outra das ideias defendidas pelos adversários em disputa, e,

5 Praças centrais das póleis gregas, onde realizavamse as atividades comerciais e as assembleias populares. mesmo não havendo leis escritas, a população parecia "já querer reivindicar para si um papel próprio e em que, por outro lado, também começam já a afirmar-se opiniões contraditórias". Por mais que essas passagens das assembleias de Iliada e Odisseia não correspondam exatamente ao que era a sociedade na época, nos textos homéricos já é possível observar elementos que justificam a emergência do fator político no seio da sociedade ateniense: a figura do orador, o apelo dos políticos ao apoio popular, o ato de evocar o direito à palavra, o princípio maioritário (vontade da maioria), dentre outros elementos que caracterizariam o sistema democrático que se estabeleceria em Atenas por volta do século V. a.C. ${ }^{6}$.

Essa "nova Atenas" do século V a.C., urbana, democrática e efervescente (habitada por cerca de 300 mil habitantes) "tinha necessidade de uma burocracia culta, que conhecesse a escrita”, o que fez com que os cidadãos livres passassem a dedicar-se cada vez mais à participação política, valorizando a oratória, a filosofia, a literatura e desprezando de maneira categórica todo

\footnotetext{
${ }^{6}$ Legisladores como Sólon (638 a.C.-558 a.C.) e Clístenes ( 565 a.C. -492 a.C.) foram responsáveis por uma série de transformações que gradualmente abriram espaço e consolidaram as instituições democráticas em Atenas. Péricles (495 a.C. - 429 a.C.) garantiu a defesa dos ideais democráticos perante as tentativas de restaração aristocráticas, assegurando, assim, a aplicação dos conceitos relacionados à democracia e à cidadania, como a isonomia (igualdade de direitos) e a isegoria (igualdade de direito à palavra nas assembleias). Destarte, o "século de Péricles" (século V a.C.) marcou a consolidação da democracia em Atenas, onde os homens livres, adultos e nascidos em Atenas poderiam participar das decisões políticas de sua pólis; mulheres, estrangeiros e escravos estavam excluídos desse processo (VERNANT, 2002).
} 
trabalho manual, relegado aos escravos e estrangeiros (CAMBI, 1999, p.84). Desse modo, a adoção do alfabeto iônico permitiu o florescimento do teatro, da poesia, das primeiras escolas e, com isso, dos primeiros professores, incumbidos da instrução de crianças e jovens em Atenas. Essas mudanças sociais constituiram a abertura necessária para o desenvolvimento de um novo ideal de educação, concebido como paideia:

Assim, a educação assumia em Atenas um papel-chave e complexo, tornava-se matéria de debate, tendia a universalizar-se, superando os limites da pólis. (...) A particularidade da educação ateniense é indicada pela ideia harmônica de formação que inspira o processo educativo e o lugar que nela ocupa a cultura literária e musical, desprovida de valor prático, mas de grande importância espiritual, ligada ao crescimento da personalidade e humanidade do jovem. Estamos já no limiar da grande descoberta educativa ateniense e também de toda a cultura grega: a paideia que, da época dos sofistas em diante, torna-se a noção-base da tradição pedagógica antiga (CAMBI, 1999, p.85).

A partir dessas reformas institucionais que culminaram na democratização da tradição aristocrática, a sociedade ateniense voltou-se cada vez mais para o domínio da palavra (logos), para a vida política e para a admissão da massa no Estado (MARROU, 1975, p.69). Com o advento do homempolítico, cidadão participativo da sociedade democrática - não mais restrito ao seu núcleo familiar e incumbido de direitos e deveres para com a sua pólis - Atenas não mais comportava o único ideal de formação aristocrático. Essa nova pólis e esse novo homem político traziam consigo, inevitavelmente, a necessidade de um novo modelo formativo: tanto a arete quanto o ideal de educação aristocráticos deveriam ser - e foram - modificados, uma vez que a velha educação pautada na ideia de nobreza de sangue não mais satisfazia as novas demandas sociais. Esse longo processo que levou ao "nascimento da paideia grega" envolveu, sobretudo, a necessidade de "superação dos privilégios da antiga educação para a qual a arete só era acessível aos que tinham sangue divino". Em oposição à arete aristocrática, "a arete política não podia nem devia depender da nobreza de sangue, se não quisesse considerar um caminho falso a admissão da massa no Estado" (JAEGER, 2013, pp. 336-337).

\section{A paideia sofística e a paideia filosófica de Platão: o domínio do logos e a educa- ção como episteme.}

$\mathrm{O}$ século $\mathrm{V}$ a.C. foi, assim, o ponto de partida histórico desse novo "movimento educativo" que daria origem à "ideia ocidental de cultura", voltada inteiramente para uma concepção político-pedagógica, nascida a partir da necessidade da sociedade democrática ateniense de proporcionar a formação de homens aptos à vida política, a individualização do "espírito humano" (no sentido de valorização das ideias e necessidades individuais) e a superação do desafio de inserção da massa nessa dinâmica, em oposição às velhas organizações de "bandos" ou tribos com minorias dirigentes, dominantes, sem a participação popular nas de- 
cisões políticas que afetavam toda a sociedade (JAEGER, 2013, pp.337-339). Nessa vida social cada vez mais comunitária e pública, o domínio da palavra e da razão (logos) passava a ser, mais do que nunca, o principal instrumento político dos cidadãos. Assim, "se desenvolve 'uma atividade educativa total e permanente, que faz da pólis inteira uma 'comunidade pedagógica"' (VEGETTI apud CAMBI, 1999, p.79), onde a cultura crítica centrada na razão - em oposição ao saber religioso e mitopoético - surge como possibilidade real de constestação e análise da realidade social, abalando, com isso, as velhas tradições.

Essa complexa formação (social, politica, cultural e educativa) colocou em crise o éthos tradicional da pólis grega, que era aristocrático-religioso, transmitido por meio do exemplo e dos processos de socialização e vivido como uma profunda - e também natural, imediata - identidade social. A pólis como organismo também educativo entra em crise; a ela se contrapõe o indivíduo, o sujeito, que vive uma profunda desorientação e é levado a buscar uma nova identidade. Trata-se de fixar modelos de homem, de cultura e de participação na vida social bem diferentes do passado, não mais sustentados pelos valores da pólis, mas, ao mesmo tempo, mais pessoais, mais individualmente escolhidos e construídos, e mais universais, mais idôneos para a formação do homem enquanto tal, sem limite de etnia, de casta, de cidadania: um homem desenvolvido de maneira mais geral e mais livre, mais apto a reconhecer e a realizar a sua própria "universalidade humana" (CAMBI, 1999, p.86).
A necessidade de um novo modelo de formação humana e, com isso, de um novo tipo de educador, permitiu o surgimento dos mestres da retórica da escola sofista7 e, posteriormente, dos filósofos socráticos, com suas diferentes perspectivas no campo da educação. Os sofistas (do grego sophós - "sábio", "professor de sabedoria”) eram professores itinerantes de retórica e oratória, vindos de várias partes da Grécia para ensinar os jovens, atendendo, assim, à demanda do contexto educacional ateniense. Como não eram de famílias aristocráticas e precisavam de trabalho para sobreviver, os sofistas cobravam por suas aulas, motivo pelo qual foram duramente acusados pelo Sócrates platônico como "mercenários do Saber" (PLATÃO, 2010a, p.61). Entretanto, ao contrário dessa visão caricatural apresentada pelos socráticos, diversos historiadores da Educação - em especial Werner Jaeger, Franco Cambi e Henri-Irénée Marrou - consideram imensurável a contribuição da sofística para o campo da Educação e da pedagogia: é a partir dos sofistas que a educação surge, em seu sentido estrito, como a própria paideia (JAEGER, 2013, p.335).

Foram os sofistas que mudaram o foco das reflexões do campo cosmológico para o antropológico, abrindo, assim, o período humanista da reflexão filosófica a partir de temas relacionados à política, moral, arte e religião; participaram ativamente na siste-

\footnotetext{
7 Para Marrou (1975, p.85), os sofistas não eram filósofos, mas pedagogos e educadores. Do mesmo modo, suas ideias eram muito diversas para considerarmos a existência de uma "escola filosófica" sofística. Dentre os principais nomes da sofística, destacam-se Protágoras de Abdera (490-421 a.C.) e Górgias de Leotinos (487 a.C.-38o a.C).
} 
matização do ensino, a partir da organização de um currículo de estudos, que envolvia gramática, retórica e dialética; na tradição pitagórica: aritmética, geometria, astronomia e música, compreendendo uma verdadeira e definitiva "revolução pedagógica" (MARROU, 1975, p.85). Ou seja, além de contribuirem para a configuração de uma nova arete política e fundamentarem a paideia poética que perduraria até o período de consolidação da Academia de Platão, os sofistas orientaram a filosofia socrática com sua proposição antropológica e sobretudo com seus questionamentos voltados para o campo da política e da moral, com sua educação retórica "típica daqueles que se empenham no governo da pólis, que mergulham na vida politica e querem participar da direção da coisa pública" (CAMBI, 1999, p.51).

O objetivo maior da sofística seria “armar, para a luta política, a personalidade forte que haverá de impor-se como chefe à cidade", tal qual Protágoras, "que queria tornar seus alunos bons cidadãos, capazes de bem conduzirem a própria casa e de gerirem, com suprema eficácia, os negócios do Estado", ou seja, "ensinar-lhes a arte da política". A "sabedoria” e o "valor" possuiria um sentido prático, pragmático: o que importa é ensinar o jovem a agir politicamente enquanto cidadão participativo. Mesmo não se aprofundando teoricamente sobre as mais diversas disciplinas (com exceção da poesia e da literatura, alicerce de seu método erístico), foram eles "os primeiros a reconhecer o valor formativo destas ciências e a faze-las entrar num ciclo normal de estudos". Com o tempo, transformaram e aprofundaram o próprio método, de modo a "sistematizar o estudo das relações entre o pensamento e a linguagem", tornando-o "uma parte preponderante de toda educação”. Assim, a educação clássica se ampara na via aberta pelos sofistas, que dedicaramse "ao estudo sério da estrutura e das leis da linguagem" e mesmo a "ciência gramatical". Sua contribuição educativa para a constituição da paideia nos é, hoje, muito clara: para os sofistas, era necessário que a criança ou o adolescente, estudasse "não para tornar-se um técnico, mas para educar-se” (MARROU, 1975, pp.88-97).

Esses professores tornaram-se os grandes porta-vozes da arete política em Atenas e os idealizadores de uma nova “educação pública, retirada da familia e do santuário, que visa à formação do cidadão e das suas virtudes (persuasão e capacidade de liderança, sobretudo)"; uma formação "moral, retórico-linguística, historica do homem político enquanto tal" ligada "à palavra e à escrita" e que "tende à formação do homem como orador, marcado pelo princípio do kalokagathos (do belo e do bom)”, visando "cultivar os aspectos mais próprios do humano em cada indivíduo, elevando-o”, enfim "a uma condição de excelência, que todavia não se possui por natureza, mas se adquire pelo estudo e pelo empenho" (CAMBI, 1999, p.86). Foi assim, na transição dos séculos V a.C. e I.V. a.C. que se desenvolveu, com os sofistas e com socráticos, a ideia de fundamental de paideia. Para Jaeger (2013, p.15):

A essência da educação consiste na modelagem dos indivíduos pela norma da comunidade. Os Gregos foram adquirindo consciência clara do significado desse processo mediante aquela imagem do Homem, e 
chegaram por fim, através de um esforço continuado, a uma fundamentação, mais segura e mais aprofundada que a de nenhum povo da Terra, do problema da educação.

Em seu sentido mais amplo, a paideia grega seria "a educação do homem de acordo com a verdadeira forma humana, com o seu autêntico ser" não derivada do invidualismo, mas de um "humanismo", baseado na "consciência gradual das leis gerais que determinam a essência humana"; um homem retratado por artistas, filósofos e poetas não como um "eu" separado, mas enquanto ideia: um "Homem genérico na sua validade universal e normativa" (JAEGER, 2013, pp.14-15). O ideal de formação integral da paideia - que engloba aspectos físicos, artísticos, morais e intelectuais - compreende ainda o homem em contato orgânico a sua cultura, em uma relação de introjeção, assumindo responsabilidades sociais e cidadãs, ou seja, "o homem só é tal por meio do comércio íntimo com a cultura, que deve estruturá-lo como sujeito e torná-lo indivíduo-pessoa" (CAMBI, 1999, p.74). Esse ideal "amadurece por intermédio da reflexão estética e filosófica e encontra na pedagogia na teorização da educação subtraída à influência única do costume - seu próprio guia”. Com a consolidação da paideia no mundo antigo - do grego e helenístico, chegando aos romanos e posteriormente aos cristãos - esse ideal de formação humana seria reelaborado através de outros modelos constituindo-se como "produto mais alto e complexo, mais típico da elaboração cultural grega e um dos legados mais ricos da cultura ocidental por parte do mundo antigo (CAMBI, 1999, p.49).
A partir da paideia, a maior contribuição dos gregos teria sido o sentimento de "individualidade", de importância e de encontro do indíviduo com o seu lugar na sociedade. Ao contrário do culto aos grandes reis, pirâmides, grandes monumentos de outras civilizações orientais e ocidentais, no mundo grego vemos o surgimento de nomes que se perpetuaram, ou mesmo a de uma vida cotidiana marcada pela valorização do individual ${ }^{8}$. Essa individualidade afetou inclusive os padrões estéticos da sociedade ateniense, que pode, pela primeira vez, reproduzir, através da arte, a natureza humana em todos seus detalhes, como nenhuma outra sociedade antiga conseguiu (JAEGER, 2013, pp. 9-10). Como paideia, a educação torna-se um projeto de emancipação do homem enquanto indivíduo, mas também do homem social, que colocará seus conhecimentos à serviço da "força formativa" a partir de um processo de construção consciente que envolve toda a sociedade.

\footnotetext{
${ }^{8}$ Assim como os historiadores e filósofos da Educação que servem como referência para o nosso trabalho, não desconsideramos a importância de outras civilizações "não-helênicas" na constituição da Educação no Ocidente. O melhor exemplo se dá a partir da influência dos educadores e escribas egípcios sobre a pedagogia e a filosofia gregas, tal qual delineada na obra de Marrou (1975, pp.11-12). Estudar a centralidade helênica na constituição dos alicerces de nossa educação não significa ignorar a contribuição de outros povos, muito menos isolar a Grécia do contexto mediterrânico, seja na Antiguidade clássica, seja em outros períodos históricos. Todavia, sua originalidade e inovação no campo da Educação, bem como a permanência de seu modelo paidêutico no decorrer da História não podem ser diminuídos, muito menos ignorados. Ver CAMBI (1999), MARROU (1975), JAEGER (2013), MANACORDA (1992) e PEREIRA (1998).
} 
O processo de transição da arete aristocrática para a arete política já estava consolidado à época de Platão. Desde o humanismo da paideia sofística, na qual o homem seria origem de todos os valores, os esforços educativos voltavam-se à formação política "do homem vinculado a um Estado jurídico". A partir dessa mudança "o pensamento teve e orientar-se vigorosamente para a questão de saber qual o caminho que a educação teria de seguir para alcançar a arete" (JAEGER, 2013, p.335). É nesse momento em que entra em cena a nova concepção paidêutica que marcaria profundamente a história da Educação ocidental, através da escola socrática. É a partir da ação educativa de Sócrates ${ }^{9}$ e Platão - inspirados e norteados pela ação dos educadores sofistas - que veremos a consolidação da paideia orientada a partir de princípios universalizantes, éticos e humanistas.

$\mathrm{O}$ período clássico compreende $\mathrm{o}$ momento máximo de desenvolvimento e complexificação da paideia, que sofre de maneira definitiva, através dos socráticos, uma "guinada filosófica", que originaria, nos períodos posteriores, diversas perspectivas sobre a mesma, bem como um pluralismo de modelos paidêuticos, mas tendo a paideia

\footnotetext{
9 Filho de um escultor e de uma parteira (de onde vem a concepção de "parturição das ideias"), pai da filosofia moral e da Ética, Sócrates traz até nós um dos maiores problemas historiográficos da filosofia ocidental: por não ter deixado registros escritos suas ideias foram transmitidas por Xenofonte e por Platão - as fontes são unânimes em ressaltar sua importância, mas é difícil precisar a sua real existência (MARROU, 1975, p.98). Por esse motivo, quando nos referimos a Sócrates, estamos nos referindo a uma figura considerada como real e histórica, mas sem desprender-se das concepções de seus discípulos que registraram suas ideias, motivo pelo qual recorremos à expressão "Sócrates platônico".
}

filosófica como "centro teórico da elaboração pedagógica da Antiguidade”. Também é a partir de Sócrates que a paideia passa abranger a universalização do indivíduo por meio da racionalidade e do autoconhecimento, atribuindo "ao homem sobretudo uma identidade cultural e histórica”, um "humanismo (ou humanitas)" que não é inerente à natureza humana, mas sim "fruto apenas da educação", constituindo-se como "o desafio máximo que alimenta todos os processos de formação” (CAMBI, 1999, pp.87-88).

A filosofia socrática orienta-se a partir de uma motivação ético-antropológica, onde o discurso especulativo dá lugar a uma ética e a uma sabedoria com finalidades práticas. Seu método baseava-se no diálogo e na maiêutica (parturição das ideais), onde a partir de uma série de questionamentos o próprio interlocutor dava luz às ideias. Com Sócrates, a filosofia grega assume um caráter de universalização e radicalização do pensamento, como um despertar interior que clama pela "liberação do indivíduo que se choca com o poder político e religioso da pólis" (CAMBI, 1999, pp.87-77). Pertencente à geração dos sofistas, foi também, "à sua maneira (...) "um educador" (MARROU, 1975, p.99).

Sócrates representou uma mudança sigificativa, a ponto de se tornar uma marca não só na história da paideia, como também na história da Educação no Ocidente. Seu ideal formação humana: 1- é alicerçado sobre o princípio da liberdade e da universalidade, amparado por um rigoroso método dialético que busca "um aprofundamento cada vez maior dos conceitos para chegar a uma formulação mais universal e mais críti- 
ca"; 2- apresenta a paideia "como problematização e como pesquisa, que visa a um indivíduo em constante amadurecimento de si próprio, acolhendo em seu interior a voz do mestre e fazendo-se mestre de si mesmo"; 3- constrói uma paideia "problemática e aberta" que "consigna um modelo de formação dinâmico e dramático, mas ao mesmo tempo individual e universal"; 4- pressupõe um modelo denso e linear, que "reconhece o caráter pessoal da formação, seu processo carregado de tensões, sua tendência ao autodomínio e à autodireção e ao fato de ser uma tarefa contínua" (CAMBI, 1999, pp.87-89). Assim, o caráter revolucionário da paideia socrática consiste na apropriação dos modelos anteriores mas atribuindo a ela um amplo sentido universal, ético e filosófico.

A geração dos sofistas e de Sócrates é sucedida pela geração de Isócrates (436-338 a.C.) e Platão, responsáveis pela maturidade da educação grega, atribuindo a ela elementos originais, delineando "de maneira nítida e definitiva, em seu próprio pensamento e na consciência antiga, os quadros gerais da cultura superior" e "os da educação". A partir de Isócrates (que abre sua escola em 393 a.C.) e Platão (que funda sua Academia em 387 a.C.) a civilização ateniense passa a abarcar dois tipos antagônicos de cultura e de educação: o modelo filosófico de Platão e modelo isocrático, voltado aos estudos da oratória (MARROU, 1975, p.103). Todavia, é somente a partir da Academia de Platão que o mundo helênico passa a englobar um espaço de formalização e aplicação prática dos ideais paidêuticos, a "fundamentação da paideia na episteme", bem como "a pretensão de uma realidade política transforma- da", onde "a paideia clássica ganha dimensões metafóricas e espirituais mais profundas 'pregando o ideal da perfeição interior realizada através da educação disciplinada"” (TARNAS apud GROSS, 2005, p.27).

Platão (cujo nome verdadeiro era Arístocles) viveu entre 427 a.C. e 347 a.C. Filho de uma nobre família ateniense, tentou se aventurar na vida política em mais de uma cidade grega, mas sua principal marca foi deixada na História da Educação e da Filosofia. Começou a estudar filosofia ainda jovem a partir das leituras de Heráclito de Éfeso (filósofo pré-socrático do século VI a.C.). Entretanto, foi o encontro com Sócrates em 407 a.C. que marcou a sua filosofia que, ao lado de Aristóteles $^{10}$, influenciou a História da humanidade e influencia até os dias atuais. A morte de seu mestre em 399 a.C. o levou a um longo exílio na Sicília, voltando a Atenas por volta do ano 388 a.C., fundando então a Academia. Sua obra $A$ República (Politeia ou Da Justiça), longo diálogo de autoria inquestionável, é considerada como um dos mais importantes textos de filosofia de todos os tempos. A tradução mais aproximada para o termo Politeia seria A Constituição, entendida como "forma de governo de um estado soberano", cujo conteúdo aborda vários temas, mas todos incidindo para o tema central: a natu-

\footnotetext{
${ }^{10} \mathrm{O}$ modelo paidêutico de Aristóteles, assim como o de seu mestre Platão, baseava-se na pedagogia como "disciplina formadora da alma e como ação civil, ligada à cidade". Contudo, seu modelo seria "mais realista e pragmático" que o anterior, como uma "correção empírica do grande e ousado modelo platônico, mas de maneira nenhuma uma refutação e um modelo alternativo. Entre os dois modelos há mais continuidade do que oposição ou diferença" (CAMBI, 1999, pp.92-93).
} 
reza e a constituição da justiça (PLATÃO, 2010a, pp.14-15).

Sua mais longa e inacabada obra de autoria inquestionável As Leis (Nomoi) nos apresenta um Platão mais amadurecido (no fim de sua vida), menos socrático do que o jovem Platão discípulo de Sócrates de $A R e$ pública. Ao contrário do primeiro diálogo cujo personagem principal é o próprio Sócrates, nas Leis o personagem principal é chamado de $O$ Ateniense. A obra revisita os fundamentos da República e nos apresenta uma nova concepção de Estado, com leis a serem aplicadas no seio da pólis, a determinação de regras de condutas para os cidadãos, superando o âmbito legal e jurídico e abrangendo também questões acerca da psicologia, gnosiologia, ética, política, ontologia, astronomia, matemática e principalmente a educação concebida enquanto formação (PLATÃO, 2010a, pp.14-15). É sobre esses dois grandes diálogos que concentraremos nossos esforços na investigação da paideia filosófica idealizada por Platão ${ }^{11}$.

Através de uma série de debates com os sofistas, o ponto central do diálogo na República envolve a definição de justiça, a formação da juventude e a constituição do Estado idealizado por Platão através de Sócrates. Para os sofistas, a arete não possuiria origem divina, sendo algo criado pelos seres

\footnotetext{
${ }^{11}$ Podemos identificar dois tipos de paideia em Platão: a paideia socrática, voltada para a formação da alma individual, presente nos diálogos Fédon, Fedro e no Banquete e a paideia política, voltada para os papéis sociais dos indivíduos, apresentando uma visão política da educação, presente na República e nas Leis (CAMBI, 1999, p.89). Sem ignorarmos os diálogos voltados para a formação da alma individual, dada a temática da nossa pesquisa, delineamos a paideia política como recorte específico do nosso trabalho.
}

humanos em determinados contextos e a partir de determinadas necessidades, motivo pelo qual as virtudes poderiam ser ensinadas. Sócrates, por sua vez, se propõe a criar junto a seus interlocutores (Gláucon e Adimanto) um Estado ideal em teoria, para explanar a sua própria concepção de justiça (PLATÃO, 2010a, p.77). Para Sócrates, os indivíduos não nascem em condições de igualdade, sendo cada um "naturalmente diferente do outro, um apto para uma tarefa, outro apto para outra”, propondo uma divisão social do trabalho especializada de acordo com as capacidades de cada indivíduo (PLATÃO, 2010a, p.93).

Dada as diferenças entre as "naturezas" de cada indivíduo, na República, os responsáveis pela legislação seriam os "homens divinos" - incluindo o próprio Platão como intermediários entre os homens e as leis, justificando a necessidade da formação dos filósofos-legisladores (JAEGER, 2013, pp.1315-1316). Existiriam, no Estado ideal, três classes fundamentais, cada qual com a sua função, exigindo, com isso, três tipos de educação fundamentados sobre a divisão social do trabalho: a educação dos produtores (aprendizado técnico), a educação dos guardiões (coragem e moderação) e a educação dos filósofos-legisladores (dialética e especulação). Dentre esses últimos, os melhores seriam escolhidos para os estudos "mais aprofundados", onde seriam treinados na arte de administrar e governar, guiados pela ideia do "Bem" (CAMBI, 1999, p.90).

Considerando as mais diversas naturezas de cada homem, caberia a esses filósofos selecionar cuidadosamente os "guardiões" do Estado de acordo com as capacidades naturais de cada indivíduo. Incumbidos 
em defender a sociedade das ameaças externas, os guardiões deveriam possuir "amor à sabedoria, animosidade, velocidade e força”, comparados a cães de caça que seriam ao mesmo tempo bravos (animosos) com os inimigos e brandos com aqueles que deveriam proteger (CAMBI, 1999, pp.101-102). Desse modo:

Na República platônica os ilustrados assumem o poder para possibilitar a formação do caráter dos subalternos segundo a imagem ideal do ser humano. Ao final de todo este processo formativo e educacional está o homem gebildete, aquele que passou pela Bildung, apropriação alemã da Paidéia - ei-lo educado, instruído, culto. Isto indica como que um quase impossível alargamento do conceito, já que a Paidéia incorpora, a partir daqui, as noções de civilização e cultura (GROSS, 2005, p.27).

Dada a sua relevância na formação de bons filósofos e bons guardiões, a educação na infância toma lugar preponderante na paideia filosófica platônica: desde cedo a criança deve ser educada com valores, no sentido de "amar a justiça" e "aborrecer o mal”. O seu logos só pode frutificar a partir do logos dos pais ou do educador, sendo a paideia "a educação do prazer e do desprazer" e sobretudo a primeira fase da arete na vida da criança (JAEGER, 2013, p.1318). Seus ideais paidêuticos tomam forma quando este afirma que a natureza (o caráter da criança) não é o suficiente para garantir a formação de um bom guardião, sendo necessário educa-la de acordo com os princípios da justiça, oferecendo "ginástica para o corpo e música e poesia para a alma” (PLATÃO, 2010a, p.104).

\section{Como já demonstrado em sua Repú-} blica, o homem, para Platão, só poderia alcançar o caminho da arete através da educação. Os princípios paidêuticos ficam ainda mais evidentes nas Leis, uma vez que, para o filósofo ateniense, a educação seria “a primeira aquisição que a criança” faz "da virtude" (PLATÃO, 2010b, p.103); dessa maneira, "todo homem que pretenda ser bom em qualquer atividade precisa dedicar-se à prática" da educação "desde a infância”, onde as crianças receberiam dos educadores brinquedos semelhantes às ferramentas reais e, posteriormente, receberiam a "instrução básica em todas as matérias necessárias” para formarem-se nas mais diversas profissões (PLATÃO, 2010b, pp.91-92). Assim, a educação adquiriria o sentido amplo de uma formação integral do homem, finalidade maior de toda ação educativa:

Em primeiro lugar e acima de tudo, a educação, nós o asseveramos, consiste na formação correta que mais intensamente atrai a alma da criança durante a brincadeira para $\mathrm{o}$ amor daquela atividade da qual, ao se tornar adulto, terá que deter perfeito domínio. (...) [A] educação que a que nos referimos é o treinamento desde a infância na virtude, $o$ que torna o indivíduo entusiasticamente desejoso de se converter num cidadão perfeito, o qual possui a compreensão. Esta é a forma específica de formação à qual, suponho, nossa discussão em pauta restringiria o termo educação, enquanto que seria vulgar, servil e inteiramente indigno chamar de educação uma formação que visa somente a aquisição do dinheiro, do vigor físico ou mesmo de alguma habilidade mental destituída de sabedoria e justiça. (...) [Aqueles] que são corretamente educados se tornam, via de regra, 
bons, e que em caso algum a educação deve ser depreciada pois ela é o primeiro dos maiores bens que são proporcionados aos melhores homens; e se ela alguma vez desviar do caminho certo, mas puder ser reencaminhada novamente, todo homem, enquanto viver, deverá empenhar-se com todas suas forças a essa tarefa (PLATÃO, 2010b, p.92).

Nas Leis, a formação maior preocupação de Platão consiste em "conseguir um legislador no mais elevado dos sentidos, isto é, um verdadeiro educador dos cidadãos", representado pela figura do filósofo, tornado protótipo do educador. A paideia deve ser vista, aqui, "do ponto de vista do educador que aspira a instalar no Estado um determinado ethos, um espírito coletivo que o enforme todo" de modo a "entender por cultura a educação para arete, que se inicia na infância e estimula no homem o desejo de vir a tornar-se um cidadão perfeito, apto a mandar e obedecer de acordo com os ditames do que é justo”. A paideia é concebida a partir de então como a "missão social do Homem” no sentido da, em oposição a educação estritamente individual constituinte da paideia socrática. Mais do que as mudanças interiores apresentadas por Sócrates, um homem integrado "dentro do Estado" que "traduz o valor da sua educação na capacidade de cooperar com os outros". É a partir das Leis que a paideia adquire um sentido social, onde a educação só faz sentido se possuir um caráter coletivo (JAEGER, 2013, pp.1310-1312), modelo orientou os modelos paidêticos posteriores e fundamentou a organização da escola moderna (CAMBI, 1999, p.91).

\section{O sentido da paideia na contempora- neidade: entre utopias e distopias.}

Não pretendemos aqui traçar uma visão etapista ou linear da História pois não existem, na prática do historiador, "processos cíclicos, lineares ou estacionários em estado puro", uma vez que "as três topologias do tempo, que por certo temos o direito de dissociar e opor para as exigências de uma análise lógica, estão na realidade ligadas uma à outra" (POMIAN apud MARQUES, 2008, p. 63). O passado, longe de estar morto ou engessado, dialoga com o tempo presente. A partir dessa perspectiva dialética, pretendemos resgatar o sentido operante da paideia no campo da Educação no período da contemporaneidade. A peculiaridade do caso grego consiste na longa duração da tradição paudêutica e do humanismo helênico. Do mesmo modo, o privilégio da razão (logos) e o agir consciente em sociedade a partir da preparação para a vida política, faz da paideia um verdadeiro "arcabouço teórico" para a sociedade política contemporânea. A expansão do helenismo fez com que Paideia florecesse, estendendesse e consolidasse durante todo o período clássico, compreendendo "um genuíno sistema educativo que veio a constituir-se em teoria e modelo matriz da educação ocidental" (GROSS, 2005, pp.32-33).

Sem desconsiderarmos as descobertas e práticas pedagógicas originais, tanto a educação romana, a educação cristã medieval quanto a educação moderna do período do renascimento foram marcadas pela retomada e até mesmo a imitação dos modelos antigos; no caso do Renascimento dos séculos XV e XVI, esse "retorno” à Grécia se 
mostra fundamental através da retomada da tradição clássica e do humanismo grego. Em diversos momentos no decorrer da História europeia - do romantismo ao nazismo, passando pelo período do renascimento e do iluminismo - intelectuais realizaram o trabalho de resgate e de ligação direta de determinado povo/geração com a antiguidade clássica, dominada pela cultura helênica (JAEGER, 2013, p.11).

Em linhas gerais, o modelo paidêutico foi transformado e incorporado pelo helenismo, posteriormente pela humanitas romana, transformando-se na paideia cristã medieval, chegando à paideia humanista iluminista - orientada pela ideia de Aufklarung (esclarecimento) - e à Bildung ${ }^{12}$ alemã dos séculos XVIII-XIX, momento em que a paideia alcançou seu pleno amadurecimento enquanto modelo formativo. No decorrer do século XIX, a tradição paidêutica permanece a partir do projeto de formação omnilateral marxiano. Para Karl Marx (2011, pp.43-45), os limites da emancipação política são determinados pelo Estado e pelo modo de produção capitalista, que impede com que o indivíduo seja verdadeiramente livre. Nesse modelo autoritário de educação, "se as circunstâncias em que este indivíduo evoluiu só lhe permitem um desenvolvimento unilateral, de uma qualidade em detrimento de outras" e "se estas circunstâncias apenas lhe fornecem os elementos materiais e o tempo propício ao desenvol-

\footnotetext{
${ }^{12}$ Assim como a paideia, a palavra alemã bildung não possui uma tradução exata para a língua portuguesa. Com o sentido original de cultura e muitas vezes traduzido como formação cultural, esse conceito possui uma forte conotação pedagógica e humanista, que considera a formação como processo formativo (BERMAN apud SUAREZ, 2006, p.193).
}

vimento desta única qualidade, este indivíduo só conseguirá alcançar um desenvolvimento unilateral e mutilado". Em contrapartida, sua proposta de formação omlilateral postula a superação da alienação imposta pelo sistema capitalista através de uma educação integral e revolucionária na luta pela emancipação humana. Essa omnilateralidade "é devedora da paideia grega e da Bildung alemã (...), na medida em que não pode prescindir de qualquer dos elementos destas (OLIVEIRA e OLIVEIRA, 2014, pp.220-221).

Para Freitag (2007, pp.107-108), a maior contribuição da Paideia grega para a Bildung alemã seria o seu princípio orientador com base no humanismo e não no individualismo, reafirmando, desse modo, a Ética como uma das maiores heranças da cultura grega. Na visão da autora, foi o filósofo Immanuel Kant (1724-1804) quem "transferiu" o conceito grego da paideia para o alemão Bildung, ao criticar a ideia de inatismo da moral: esta deveria ser ensinada desde a infância, momento em que a criança aprende a "controlar seus excessos e suas paixões, para depois aprender o exercício da ética e da cidadania”. A moralidade não está, pois, "embutida no recém-nascido", mas pressupõe uma longa formação pautada na Ética - como na Paideia e na Bildung - voltada para a construção de uma consciência moral.

Suarez (2006, pp.196-198) considera que foi o historiador da arte Johann Joachim Winckelmann (1717-1768) o "criador de uma luminosa visão apolínea da Grécia" na Alemanha do século XVIII, onde a Antiguidade clássica tornou-se "modelo e arquétipo" no 
campo da arte e da literatura, justificando, a partir de então, o "resgate" da antiguidade e a imitação dos antigos gregos como constituinte do ideal de formação da Bildung. Essa essência dinâmica da Bildung como retorno ao domínio do logos do mundo helênico, buscando um equilíbrio entre ciência, arte e filosofia, esteve presente na filologia alemã, de Schlegel à Nietzsche como uma verdadeira "viagem formadora à Grécia antiga".

A partir da Bildung, o potencial crítico, humanista e formativo da paideia é colocado em primeiro plano na busca pela superação de uma educação fragmentada, especializada e acrítica, que carrega o nome "integral" somente no plano teórico. Para Freitag (2007, p.114), a busca pela paideia contemporânea seria a busca por uma formação que supere a divisão das disciplinas escolares obrigatórias, que possibilite que à criança "lidar com o mundo, seus problemas, seus temas através do esporte, da música, da leitura, da arte, do teatro, do cinema, enfim, das Humanidades lato sensu". Em uma perspectiva semelhante, Gross (2005, p.13) tem no conceito de utopia um dos elementos centrais na discussão sobre a Educação contemporânea. Para o autor, utopia e paideia além de caminharem lado a lado, compreendem-se enquanto elementos estruturantes do pensamento filosófico no campo da Educação. Nessa perspectiva, a busca por uma nova sociedade, desde a Antiguidade até os dias atuais seria um dos principais objetivos dos ideais de formação: “a paideia de Platão, inserida num amplo projeto político, permanecerá na cultura ocidental como um modelo-máximo, sempre marcado por fortes implicações utópicas".
Desde sua Alegoria da Caverna, Platão teria indicado que o caminho da libertação - ou seja, a busca pela realização da própria paideia - é um caminho individual, mas que "não exclui a conotação social, já que o homem se educa para viver em sociedade", sendo este "sempre concebido como uma unidade em si e para si”, ideia que influenciou de forma ampla a Bildung e a concepção de formação omnilateral marxiana. Eis uma das maiores contribuições de Platão para todos os modelos formativos paidêuticos que se desenvolveram no decorrer da História da Educação ocidental: não distinguir ou discriminar "a ética, a estética, a política e a educação, já que todos estes conceitos formavam" em sua paideia "uma unidade globalizada", ideia fundamental na constituição dos ideais de formação integral, abarcando a cultura, os valores individuais e as questões sociopolíticas (GROSS, 2005, p.32).

Discutindo o sentido e a validade da formação cultural (Bildung) no contexto da pós-modernidade e sob o domínio da racionalidade instrumental, Herman, por Mölmann (2010, pp.2-3) afirma que, a partir da contribuição da primeira geração dos teóricos críticos da Escola de Frankfurt - especialmente Theodor Adorno (1903-1969) e Max Horkheimer (1895-1973) - houve uma desconstrução dos ideais do iluminismo, o que permitiu revelar "o poder coercitivo da razão, ao contrário de sua pretensão emancipatória”. Segundo Gomes (2010, p.200), desde Kant, o esclarecimento (Aufklarung) era uma condição para a emancipação; contudo, ao contrário das pretensões iluministas, a sociedade contemporânea seria uma sociedade "supostamente" esclarecida, que 
na verdade, não passa de uma "sociedade administrada" na qual "os indivíduos se veem completamente anulados em face do poder econômico, da visão utilitária e da racionalidade técnico-instrumental”, levando essa mesma sociedade à uma "condição de alienação e enclausuramento”.

Em sua Teoria da Semicultura ou Teoria da Semiformação (1959) Adorno considera que a sociedade capitalista impede o pleno desenvolvimento da cultura, que semiforma ao invés de formar os sujeitos. Em oposição a uma formação cultural crítica e emancipadora (elementos paidêuticos da Bildung e da omnilateralidade), a semiformação (halbbildung) compreende uma educação pautada no modelo de racionalidade totalitário, reprodutor do autoritarismo, da insensibilidade, da frieza, do ódio e da violência. Amparadas pela escola, pela família e pelo Estado, as ações semiformativas destroem a formação autônoma e atingem a sociedade como um todo, não somente o campo da educação formal (ADORNO, 2010). Nessa relação, a formação (bildung) converteria-se em semiformação (hallbindung), levando ao esvaziamento ou instrumentalização dos ideais de liberdade emancipação da paideia e da bildung (GOMES, 2010, p.200).

Os "estudos de frieza" de Andreas Grushka (2014) indicam que que mesmo com pretensões pedagógicas baseadas em princípios éticos - ou mesmo paidêuticos muitos profissionais, incluindo os professores, não percebem a sutileza com que a frieza - elemento fundamental na subjetividade burguesa - se reproduz nas práticas cotidianas no contexto escolar. Dos discursos dos gestores aos textos que servem como bases curriculares para a prática docente, uma ordem moral e justa é vislumbrada, com base da promessa de uma universalidade social da formação e de uma educação solidária. Entretanto, apesar do discurso próemancipação, a realidade mostra a frieza da sociedade produtiva, marcada pela competição e pelo individualismo capitalistas. Essa frieza tão comum nos espaços escolares impede a formação de uma sociedade humana, trazendo, em contrapartida, a insensibilização como fruto do próprio processo educativo. Destarte, as contribuições da teoria crítica no campo do ensino mostram a nós, educadores, que "o potencial da razão, tornado possível através do Iluminismo, até hoje não se desenvolveu realmente na sociedade" (GRUSHKA, 2014, p.15).

Criticando o abandono ou esvaziamento da educação política e o "reducionismo da formação à sua dimensão técnicoinstrumental”, Gomes (2010, pp.198-199) propõe uma reflexão sobre o sentido político da educação, visando uma "atitude crítico-formativa” capaz de realizar um projeto de emancipação social. Para tanto, é necessário repensar a política "enquanto dimensão vital da sociedade”, essência da paideia grega e da bildung alemã, superando sua redução à esfera "administrativa e gerencial”. Para Gross, frente a essa racionalidade instrumental, seria necessário a reconstrução de uma paideia crítica enquanto utopia e modelo formativo:

A ideologização, a homogeinização, a irrelevância do hoje, o desconhecimento do passado, a imponderabilidade do futuro, a ausência do sentido da vida... não é este o quadro descritivo da atualidade? E não são eles próprios indicadores da ne- 
cessidade da retomada da Paidéia no seu vigor utópico original? (...) A retomada, neste início de milênio, dos verdadeiros fins da educação, que dêem aos seres humanos a sua dimensão universal e atemporal, é esta a tarefa da Paidéia Crítica. A reflexão filosófica, baseada na ética e na metafísica fará do filósofo um educador e do educador um filósofo. (...) A reflexão filosófica e paidêutica é o caminho que se indica para esta retomada. Mas uma reflexão confrontada com a pluralidade complexa de questões psicológicas, antropológicas, sociais e econômicas. Uma retomada de princípios educacionais e educativos que fujam do mascaramento ideológico, e que esteja em consonância não com o novo, mas com o permanente. E o que é permanente em educação? É a pedagogia que não perde de vista a busca da perfectibilidade humana (GROSS, 2005, pp.122-123).

\section{Conclusão}

O resgate e a reconstrução das utopias formativas surgem, hoje, como possibilidades de alicerçar um novo modelo de educação verdadeiramente integral, omnilateral e, de fato, formativo. Para Manacorda (1992, p.360), as utopias podem permitir "tomadas de consciência mais radicais", desde que concebam não somente a escola, mas toda a sociedade como o pantakhou platônico, ou seja, um projeto orgânico onde toda a sociedade constitua-se como uma comunidade formativa. Nessa perspectiva, o homem deve ser educado de acordo com a perspectiva omnilateral marxiana, pois "nenhuma batalha pedagógica pode ser separada da batalha política e social". Para que essa formação se efetive, a dimensão socioantropológi- ca da paideia e da bildung não pode ser reduzida à simples instrução voltada para a formação de mão de obra qualificada para atender às demandas econômicas capitalistas (MÖLMANN pp.2-3). Assim como Adorno (200o, p.123), acreditamos que, a resistência à instrumentalização dos modelos paidêuticos e o esvaziamento do sentido político da formação só pode ocorrer através de uma autorreflexão crítica, com foco na autonomia e na autodeterminação dos sujeitos: uma verdadeira educação para a emancipação desde a primeira infância, aliada a um "esclarecimento geral" e consciente da sociedade, criando "um clima intelectual, cultural e social" que impeça a reprodução da barbárie.

A partir desses questionamentos, concluimos que, para além da formação individual, a paideia grega, em especial a paideia filosófica de Platão apresenta-se como uma verdadeira utopia social, portanto, fundamental na luta pela emancipação. O humanismo e o sentido político-antropológico da arete sofística, bem como os ideais socráticoplatônicos de justiça, autoconhecimento, introjeção, universalidade do homem, ética, responsabilidade social, como também a centralidade e o caráter político da educação, surgem como possibilidades para a fundamentação teórica de uma paideia crítica contemporânea. Assim, na contramão dos retrocessos advindos da racionalidade instrumental e de um modelo de educação cada vez mais especializado e unilateral, o resgate aos ideais ético-humanistas da paideia surge como uma possibilidade de (re)construção de uma formação cultural e política de caráter crítico, combativo e om- 
nilateral, a serviço da emancipação e da construção dos sujeitos éticos.

\section{Referências}

ADORNO, T.W. Educação e Emancipação. Trad. Wolfgang Leo Maar. $2^{\underline{a}}$ ed. Rio de Janeiro/São Paulo: Paz e Terra, 2000.

Teoria da Semiformação. In: PUCCI, ZUIN E LASTÓRIA (orgs). Teoria Crítica e inconformismo: novas perspectivas de pesquisa. Campinas-SP: Autores Associados, 2010. p.7-40.

BURKE, P. História e Teoria Social. 2ª ed. São Paulo: Editora Unesp, 2012.

CAMBI, F. História da pedagogia. Trad. de Álvaro Lorencini. São Paulo: Fundação Editora da Unesp (FEU), 1999.

FINLEY, M. I. Mito, memória e história. In: Uso e abuso da história. São Paulo: Martins Fontes, 1989.

FREITAG, B.R. Entre a paideia e a bildung: pistas para uma educação humanística. Revista de Ciências Sociais. Fortaleza, v. 38, n. 1, 2007, p. 106-114.

GOMES, L.R. Teoria Crítica, Educação e política. In: PUCCI, B.; A.S.ZUIN;

L.A.C.N.LASTÓRIA (orgs). Teoria crítica e inconformismo: novas perspectivas de pesquisa. Campinas-SP: Autores Associados, 2010. p. 197-215.

GROSS, R. Paideia: as múltiplas faces da utopia em pedagogia. Tese (doutorado) - Universidade Estadual de Campinas, Faculdade de Educação, 2005.

GRUSHKA, A. Frieza burguesa e educação: a frieza como mal-estar moral da cultura burguesa na educação. Campinas - SP: Autores Associados, 2014.

HOMERO. Ilíada. Trad. Carlos Alberto Nunes. $25^{\underline{a}}$ ed. Rio de Janeiro: Editora Nova Fronteira, 2015a. teira, 2015b.

Odisséia. Trad. Carlos Alberto Nunes. 25를 ed. Rio de Janeiro: Editora Nova Fron-

JAEGER, W. Paideia. A formação do homem grego. 6ª̀ed. São Paulo: Martins Fontes, 2013. MANACORDA, M.A. História da Educação: da Antiguidade aos nossos dias. Trad. Gaetano Lo Monaco. $3^{\underline{a}}$ ed. São Paulo: Cortez/Autores Associados, 1992.

MARQUES, J.B. O conceito de temporalidade e sua aplicação na historiografia antiga. Revista de História, $\mathrm{n}^{\circ} 158,1^{\circ}$ semestre de 2008, p.43-65.

MARROU, H. História da Educação na Antiguidade. São Paulo: EPU, 1975.

MARX, K.; ENGELS, F. Textos sobre Educação e ensino. Campinas-SP: Navegando, 2011.

MÖLLMANN, A.D.S. Bildung na contemporaneidade: qual sentido? V Congresso Internacional de Filosofia e Educação. Maio de 2010, Caxias do Sul-RS. p.1-18. Disponível em: 
http://www.ucs.br/ucs/tplcinfe/eventos/cinfe/artigos/artigos/arquivos/eixo_tematico4/Bild ung\%2ona\%2oContemporaneidade\%2oqual\%200\%2osentido.pdf . Acesso em 31/07/2017. MOSSÉ, C. A Grécia Arcaica de Homero a Ésquilo. Lisboa: Edições 70, 1984.

OLIVEIRA, A.R.; OLIVEIRA, N.A. O modelo de formação omnilateral a partir da teoria de Karl Marx. In: BOMBASSARO, L.C.; DALBOSCO, C.A.; HERMANN, N.(orgs). Percursos hermenêuticos e políticos. Homenagem a Hans-Georg Flickinger. Porto Alegre: EdiPUCRS, 2014. p.208-222.

PEREIRA, M.H.R.P. Estudos de história da cultura clássica. vol.I. Cultura Grega. 8ª ed. Lisboa: Fundação Calouste Gulbenkian, 1998.

PLATÃO. A República. 2ª Ed., São Paulo: Edipro, 2010a. . As Leis - Incluindo Epinomis - 2ª Ed., São Paulo: Edipro, 201ob.

SUAREZ, R. Nota sobre o conceito de Bildung (formação cultural). Revista Kriterion, vol.46, n.112. Belo Horizonte-MG, dezembro de 2005. p.191-198.

VERNANT, J.P. As origens do pensamento grego. Trad. Ísis Borges B. da Fonseca. Rio de Janeiro: Difel, 2002.

Recebido em: 01/08/2017

Aprovado em: 31/10/2019 